\title{
Snow-avalanche history reconstructed with tree rings in Parâng Mountains (Southern Carpathians, Romania)
}

\author{
Corina TODEA ${ }^{1}$, Olimpiu Traian POP ${ }^{1 *}$, Daniel GERMAIN ${ }^{2}$ \\ ${ }^{1}$ Laboratory of Dendrochronology, Faculty of Geography, Babeş-Bolyai University, Cluj-Napoca, \\ Romania \\ ²Département de Géographie, Université du Québec à Montréal, Montréal, Canada
}

Received 4 December 2020; Revised 16 December 2020; Accepted 17 December 2020

"Correspondence to: Olimpiu Traian POP; e-mail: olimpiu.pop@ubbcluj.ro

\begin{abstract}
Snow avalanches are a common phenomenon in Parâng Mountains (Southern Carpathians, Romania) perturbing tourism activities and associated infrastructures, damaging forests, and causing fatalities. Its past history is an essential information to gather while assessing the hazard zonation areas. Usually, in Romania snow-avalanche activity occurring in forested areas are neither monitored, nor recorded by historical archives. In these areas, environmental archives such as tree rings may provide useful information about the past avalanche activity. The purpose of the present study is to reconstruct snow-avalanche history with tree rings along a path located below Cârja Peak (2405 $\mathrm{m}$ a.s.l.), an area where past snow-avalanche activity still remains underestimated. In this sense, 57 Norway spruce (Picea abies (L.) Karst.) trees showing clear signs of disturbance by snow avalanches were sampled and the growth anomalies associated with the mechanical impact produced by snow avalanches on trees were identified within their rings and served to reconstruct past events. The reconstructed chronology covers the period 1994-2018 showing the occurrence of a minimum of 11 major events, with an average return period of 2.1 years. Tree-ring records provided the most consistent avalanche event chronology in the study area. Although the limited extension of the chronology back in time, a better understanding of snow-avalanche history which may be gained through dendrochronological reconstructions represent nonetheless useful and pertinent information to consider before the implementation and development of infrastructure in this mountain avalanche-prone area.
\end{abstract}

KEYWORDS snow avalanches, dendrogeomorphology, return periods, Picea abies (L.) Karst., Parâng Mountains (Romania)

\section{Introduction}

Snow avalanches (SAs) are known as a common phenomenon occurring in snow-covered mountainous areas worldwide, being one of the main agents of debris transfer in such environments (e.g., Rapp, 1959; Gardner, 1970; Ward, 1985; Decaulne and Saemundsson, 2006). As they can frequently endanger constructions, affect tourist activities and related infrastructures, and cause fatalities especially 
during backcountry recreation, it is of paramount importance to evaluate the risk related to the dynamics of snow avalanches for an accurate hazard zonation, but also to prevent future exposure of people and tourist infrastructures in such avalanche-prone areas. The past SAs history, especially regarding their magnitudes and frequencies are an essential information to gather while assessing the hazard zonation areas. However, SAs activity occurring in remote forested mountain areas are neither monitored, nor recorded by historical archives. In these areas, environmental archives such as tree rings may provide useful information about the past frequency and magnitude of avalanche activity (Schaerer, 1972; Rayback, 1998; Boucher et al., 2003; Germain et al., 2005; Casteller et al., 2007; Reardon et al., 2008; Muntán et al., 2009; Corona et al., 2010a, 2012; Decaulne et al., 2012; Voiculescu and Onaca, 2013; Šilhán and Tichavský, 2017). Tree-ring investigations rely on the assumption that annual growth rings record accurately and objectively, in their anatomical structure, the mechanical impact of snow avalanches on trees.

In the last decades, the western and eastern flanks of the Parâng Mountains (Southern Carpathians, Romania) have become an attractive area for winter recreational activities. This recent increase in tourist numbers, coupled with the projected increase with the development of appropriate infrastructure to sustain winter recreational activities, was planned in an avalanche-prone area, which could result in an increased exposure of people and infrastructure to avalanche hazards. In this regard and considering the lack of knowledge regarding SAs activity in this high mountain area, the absence of forecasting and warning services, tourists may cross either unconscientiously or even conscientiously some avalanche paths and hazard zones. Giving the availability of trees as natural archives on these forested slopes on the SW flank of Parâng Mountains, tree-ring-based snow-avalanche reconstructions have already been established along two adjacent avalanche paths and for several decades, up to one century (Pop et al., 2016; Meseşan et al., 2019). However, these two avalanche paths showed discrepancies in avalanche regime, likely related to their slope aspect as well as their morpho- metric characteristics. Nearby, another avalanche path appears of interest considering the tragic event that occurred on December $1^{\text {st }} 2017$, when an avalanche released below Cârja Peak (2405 m a.s.l.) and buried two people, one of whom later died. SAs activity along the path below Cârja Peak still remains underestimated, but a dendrogeomorphic investigation does provide useful information for a better knowledge of the avalanche regime, and subsequently adequate zoning. The aim of the present study is therefore to reconstruct snow-avalanche history with tree rings along the path below Cârja Peak in the Parâng Mountains. From the hazard management perspective, a better understanding of SA history in the area which may be gained through dendrochronological reconstructions should contribute significantly to hazard zoning and the establishment of appropriate risk mitigation measures.

\section{Study area}

The Parâng Mountains belongs to the Southern Carpathians Range (Fig. 1) and are one of the highest Mountain Range in Romania, with crests and peaks above 2500 m (Parângul Mare Peak, 2519 m a.s.l.). The complex geology of the area is characterized by schists and granitic intrusions in the central mountain area, and sedimentary rocks amongst them with limestones in the southern part (Badea et al., 2001). Evidence of Pleistocene and Holocene glacial and periglacial activity is well-attested by the alpine landscape morphology: narrow crests, simple and complex glacial cirques, nivation cirques, $U$-shaped glacial valleys, moraine deposits, etc. (Urdea et al., 2011). The glacial landforms are better developed on the northern slopes. On steep slopes above $25^{\circ}$, SAs are a widespread present-day process and particularly at high-elevation with glacial and periglacial ones (Gavrilă et al., 2018). The timberline is found between 1700 and $1800 \mathrm{~m}$ a.s.l., but avalanches are lower than this limit as evidenced by the presence of corridors devoid of mature forest vegetation along upper reaches valley. The avalanche path investigated $\left(45^{\circ} 22^{\prime} \mathrm{N}, 23^{\circ} 35^{\prime} \mathrm{E}\right)$ is located on the western flank of Parâng Mts., below Cârja Peak (2405 m), ranging between $2200 \mathrm{~m}$ and $1500 \mathrm{~m}$ a.s.l. (Fig. 2). The avalanche path as delineated on the orthophotos has a surface area of $910.466 \mathrm{~m}^{2}$ 
(based on a DEM with a 10-m accuracy). The slope profile shows steep slopes $\left(25^{\circ}\right.$ to $\left.45^{\circ}\right)$ in the starting and the track zones and lower slope angles (< $25^{\circ}$ ) in the runout zone. The morphology of the valley limits the lateral spread of avalanches, resulting then in a typical funnel-shaped avalanche path. The path is clearly visible by comparison to the adjacent forest. Along the track and runout zones, one can observe that tree cover is replaced by a mix of shrubs (Pinus mugo and Juniperus communis) and sparse coniferous (Picea abies (L.) Karst.) and deciduous (Acer pseudoplatanus) trees related to the frequency of avalanches. In the starting zone, the path is crossed by the main hiking trail used by tourists that follow the mountain crest, which represents a significant risk, especially during winter and spring seasons. Lower in the track zone, the path is also crossed by an additional unmarked hiking trail.

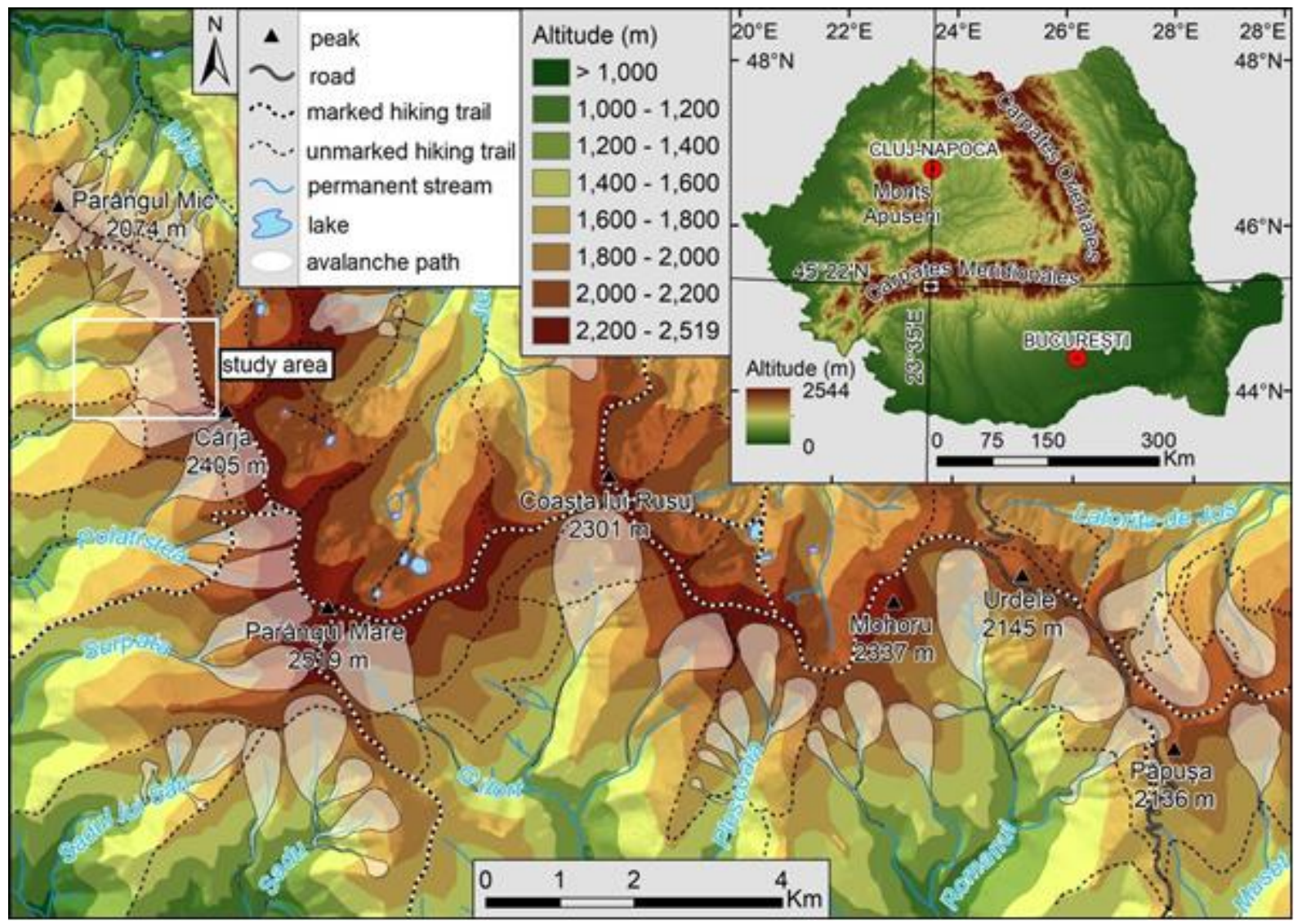

Figure 1 Location of the study area

\section{Materials and methods}

\subsection{Field sampling}

The path investigated was mapped using a 1:25000 scale topographical map and 1:5000 scale orthophotoplans (2012 campaign). A fieldwork campaign was conducted in August 2018. During fieldwork, a total number of 57 Norway spruce (Picea abies (L.) Karst.) trees were sampled. The samples were collected only from trees showing visible disturbances caused by the mechanical impact of avalanches, e.g., tilted stems, injured stems, decapitated trees, trimmed crown, and partially uprooted trees. Sam- ple collection included either discs cut from 29 trees, as well as cores extracted from 28 trees $(2,3$ or 4 cores per tree, 60 cores in total). Even not very large, the sample depth is coherent with the spatial extent of the path in the study site, as well as with the tree-cover conditions. The sampling strategy consisted also to collect samples from trees belonging to different age classes. Younger trees with high stem flexibility are more sensitive to the recent avalanche activity, showing then stronger reactions in their annual rings. By comparison, older trees are considered on one hand less sensitive to recent ac- 
tivity, but they can provide on the other hand a longer SAs chronology as they might have recorded events in the earlier decades of their lifespan (Stoffel et al., 2013; Stoffel and Corona, 2014). For each sampled tree, additional information was gathered, including tree height, the social position of the tree within the forest, nature and position of visible disturbance on stems, the position and height of the samples on the stem, as suggested by Stoffel and Bollschweiler (2008). Besides the information regarding tree morphological characteristics, photos of each sampled tree were gathered, as well as their location by using a GPS device. In addition, 22 spruce trees located outside the avalanche path in a forest stand undisturbed were also sampled (two cores per tree, 44 cores in total), in order to obtain a local reference chronology, which represents the common growth variation of trees in the area (Cook and Kairiukstis, 1990; Schweingruber, 1996). This reference chronology was used for cross-dating the growth series of disturbed trees and to distinguish the growth anomalies related to mechanical impact of SAs from those related to local stand growth conditions (Stoffel et al., 2006).

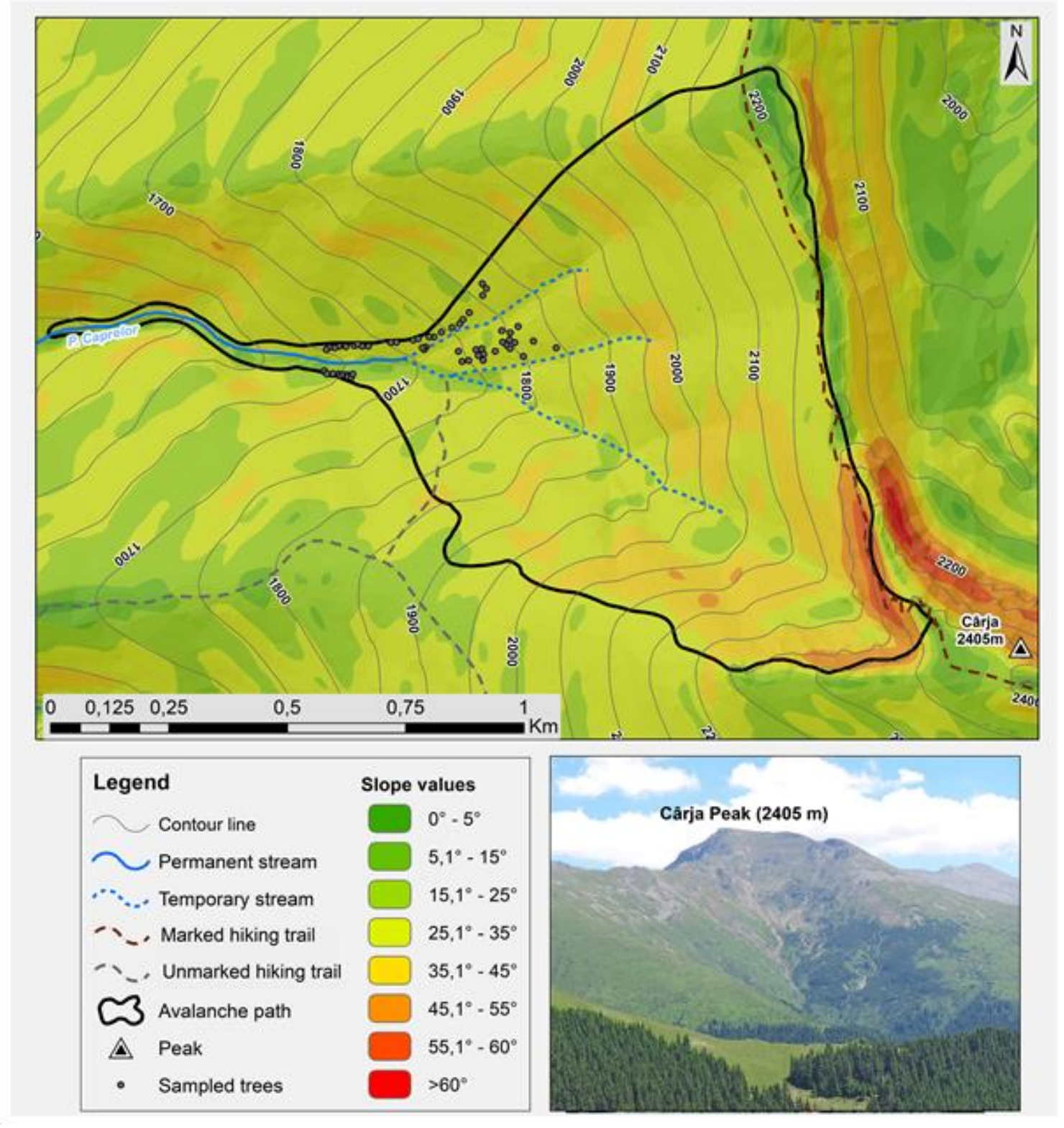

Figure 2 Delineation of the avalanche path and location of sampled trees within the path 


\subsection{Sampling preparation and analysis}

The samples were prepared for analysis following the procedures described by Bräker (2002) and Stoffel and Bollschweiller (2008). Working procedure includes core mounting in wood supports, air-drying and sanding of samples using a sanding belt machine. Successive sanding operations were applied using an increasing grits of the sanding belts (80, $180,220,400,600$ grits), in order to obtain wood surfaces suitable to reveal clearly the ring boundaries and their anatomical structure. The age of each sample was determined by ring counting under the stereomicroscope. Tree-ring width was then measured along two, three or four radii for cores and along four radii for cross-sections. Ring-width measurements were performed to the nearest of $0.01 \mathrm{~mm}$ accuracy using a LINTAB 5 system composed of Leica DMS 1000 stereomicroscope connected to the measurement table and to the computer with TSAPWin ${ }^{\text {TM }}$ Scientific software (Rinntech, 2020). Tree-ring series of trees growing outside the avalanche path were also measured to establish a local reference chronology. The calendar year of each ring in the disturbed tree growth chronologies was determined by cross-dating with the local reference chronology. The quality of the cross-dating was visually evaluated using the graphical function of the TSAP-Win software and statistically analysed using COFECHA software (Holmes, 1983).

\subsection{Growth anomalies identification and event reconstruction}

Ring-width series measured on samples from disturbed trees were visually cross-dated against the reference chronology, in order to (i) detect possible false or missing rings and to correct ring-width series of disturbed trees, and (ii) discriminate between growth anomalies related to SAs activity and the normal growth related to climate conditions (Bryant et al., 1989). Corrected growth chronologies of disturbed trees were analysed in order to identify the specific growth anomalies related to the SAs activity within tree-rings. Typical growth reactions related to mechanical impacts of SAs (Stoffel and Corona, 2014), e.g., impact scars (SC), traumatic resin ducts (TRD), compression wood (CW) in association with the onset sequences of abrupt growth suppression
(GS) were identified within rings of disturbed trees. Growth reactions developed in the first decade of the disturbed trees were disregarded for event reconstruction, as young trees having commonly thin stems are more susceptible to disturbances by various factors other than SAs and therefore represent potentially a source of dating errors (Stoffel and Bollschweiler, 2008; Šilhán and Stoffel, 2015; Tichavský et al., 2017). The avalanche chronology was reconstructed using the Avalanche Activity In$\operatorname{dex}(A A I)$ - an equation which includes the number of trees showing growth anomalies during a particular year $\left(R_{t}\right)$ divided by the total number of sampled trees alive in a specific year $\left(A_{t}\right)$ (Shroder, 1978, Butler and Malanson, 1985):

AAI $=\left(\sum_{i=1}^{n} R_{t} / \sum_{i}^{n}={ }_{1} A_{t}\right) \times 100$

To distinguish between the tree growth reactions caused by mechanical impact of SAs from those considered as a noise and recorded by trees, five growth disturbance (GD) intensity classes were defined, as proposed by Stoffel and Corona (2014):

- GD Intensity 5: SC, strong TRD;

- GD Intensity 4: moderate TRD, strong CW, strong $\mathrm{GS}$;

- GD Intensity 3: moderate CW and moderate GS;

- GD Intensity 2: weak CW;

- GD Intensity 1: weak TRD.

The intensity of each reconstructed avalanche event was determined based on the intensity classes (Stoffel and Corona, 2014) of the GDs found within the tree rings. For each class of intensity, a specific value was accorded as reported by Koglenig-Meyer et al. (2011):

$W_{i t}=\left[\left(\sum_{i=1}^{n} T_{5} \times 5\right)+\left(\sum_{i=1}^{n} T_{4} \times 4\right)+\left(\sum_{i=1}^{n} T_{3} \times 3\right)\right] \times$ $\frac{\sum_{i=1}^{n} R_{t}}{\sum_{i=1}^{n} A_{t}}$

where $T 5$ is the number of trees with GD intensity class 5 , multiplied by a factor 5 ; T4 is the number of trees with GD intensity class 4 , multiplied by a factor $4 ; T 3$ is the number of trees with GD intensity class 3 , multiplied by a factor $3 ; R$ is the number of trees showing GDs in the year (t) and $A$ is the total number of sampled trees alive in the year $(\mathrm{t})$.

Finally, a specific year was considered as being an event year if the following three conditions are fulfilled simultaneously: (i) $>10$ available trees of 10 
years old for the reconstruction; (ii) a minimum of three trees showing severe or moderate growth disturbances; and (iii) a minimum AAI of $10 \%$.

Considering that SAs occur during the winter and spring seasons, which is the dormant period of trees, they can only be recorded in the growth rings of the following summer and fall seasons. For example, the reconstructed event year 2018 means that a SA occurred during the cold season 20172018 (winter and spring).

\section{Results}

\subsection{Age structure of the forest stand}

The age of the sampled trees is variable, the youngest tree is 15 years old and the oldest one reaches
145 years old. Figure 3 shows the spatial position of sampled trees and the tree-age classes. One can observe that the older trees are located to the path margins where could indicate less impact of the SAs. A group of young trees (classes 14-18 years old and 19-30 years old) and medium aged trees (class 3150 years old) is located in the axial area of the path and seems to indicate that the avalanche path affected repeatedly this area and consequently disturbed trees cannot reach significant heights. The right side of the path is characterized by younger trees (class 19-30 year old) than on the left side (3150 years old). This suggests that SAs flow closer to the right side of the path, having then a higher impact on the forest.

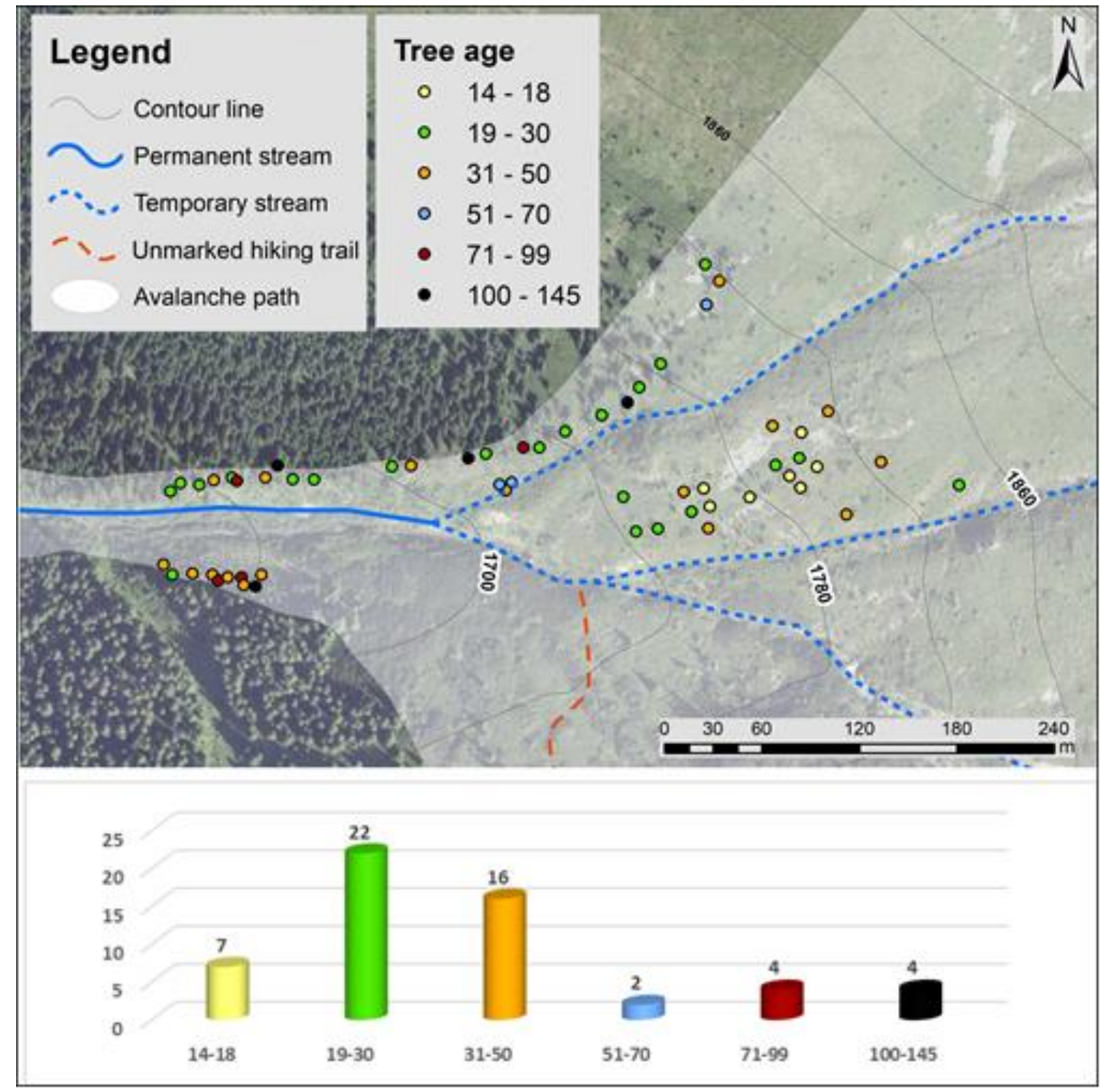

Figure 3 Spatial distribution and age classes of the sampled trees 


\subsection{Reconstructed avalanche events, frequency and spatial distribution}

Tree-rings analyses enabled to identify a total number of 354 growth anomalies, among which 185 growth reactions of severe and moderate intensities (GD intensity classes 3 to 5). Taking into consideration the three criteria above-mentioned in the method section, a minimum of $11 \mathrm{SA}$ events was reconstructed. The chronology spans the period 1994 - 2018. Other possible event years could be reconstructed, but the small number of growth reactions, in combination with a reduced sample depth and an $\mathrm{AAI}<10 \%$ do not enabled us to consider with confidence these years.

The large number of cross-sections available in the sample collection enabled to identify a large number of scars (SCs) and strong traumatic resin ducts (TRDs), two reliable indicators representing higher percentage than all the other types of growth reactions. Therefore, even though the reconstructed chronology is short, the event years that were recorded show strong and undoubtedly signals of snow avalanche activity. Table 1 shows the types and the number of growth disturbances for each reconstructed event year. Compression wood (CW) sequences resulted as a reaction to the stem tilting were also identified within the samples. Series of growth suppressed rings following the tree topping represent a valuable indicator of SAs and can be found as long sequences especially in the case of the event years with high number of trees disturbed (e.g., 2005 and 2007). Figure 4 provides some examples of typical growth reactions identified within the samples and used for event reconstructions. Figure 5 illustrates the event years within the reconstructed chronology which covers a short period of 24 years. The length of the reconstructed chronology is limited by the age of the sampled trees. However, this may also suggest that a recurrent SAs activity destroyed repeatedly the forest cover within the path. The highest number of disturbed trees was recorded in 2005 and 2007, when the percentage of affected trees is above $30 \%$ from the total sampled trees. That represents a strong signal of disturbances occurring during the previous dormant seasons, i.e., snow avalanches occurring during winter seasons 2004-2005 and 2006-2007. During winter season 2011-2012, several trees were also strongly impacted by SAs, as this year recorded the most scar-type reactions (seven in total) from all event years in the chronology. Few other years (e.g., 1997, 1991) reached the threshold of AAI $>10 \%$, but they were not considered as event years because less than three trees showed severe or moderate growth disturbances.

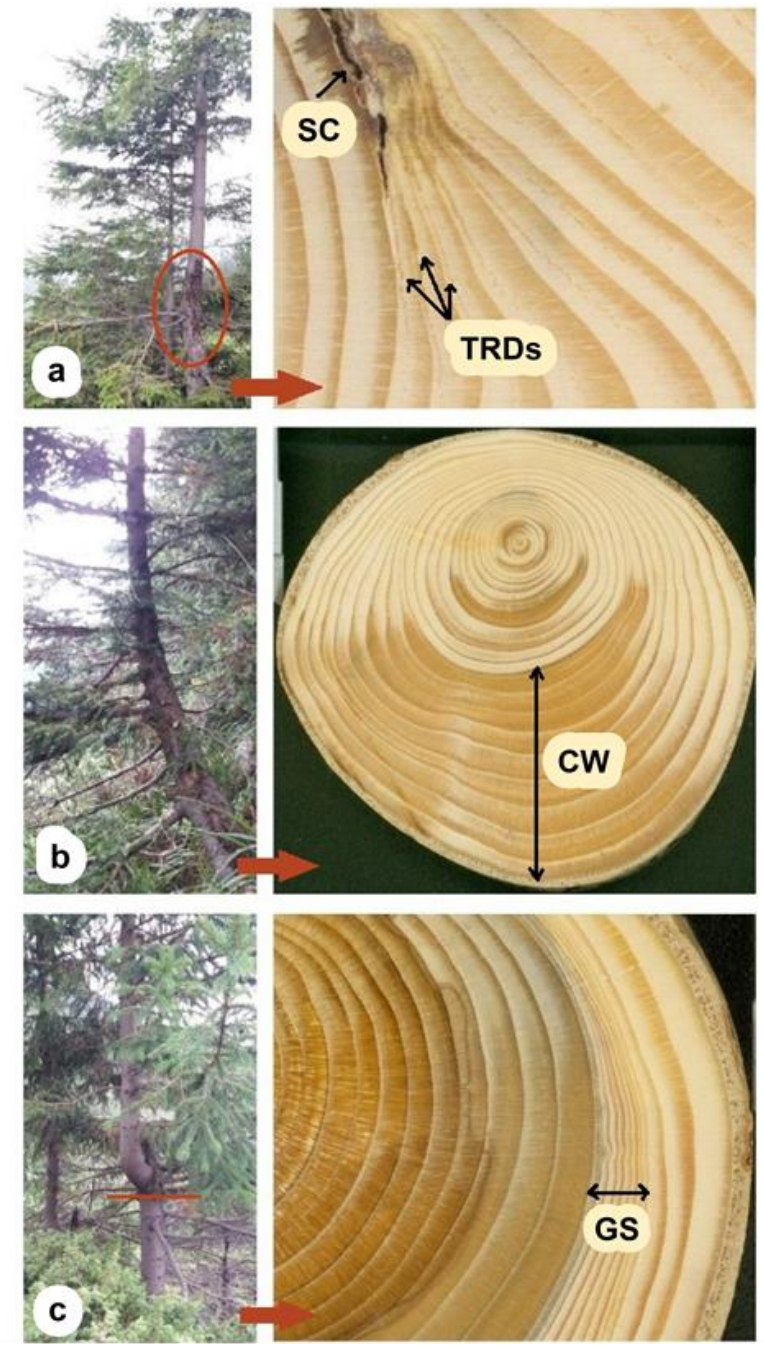

Figure 4 Examples of disturbed trees sampled and their growth reactions related to mechanical impact of SAs: (a) wounded tree due to mechanical impact of the avalanche and scar (SC) overgrown by subsequent tree rings and associated rows of traumatic resin ducts (TRDs) in the following rings after the disturbance; (b) tilted (sabre-like form) stem and its associated growth reaction, a compression wood (CW) sequence formed in several rings after the disturbance; (c) topped (apex loose) tree stem and associated growth suppressed (GS) rings 
TODEA et al. / Revista de Geomorfologie 22 (2020)

Table 1 Type, intensities and number of growth disturbances identified within rings and used in the SAs reconstruction

\begin{tabular}{|c|c|c|c|c|c|c|c|c|c|c|c|c|c|c|}
\hline & SC & $\begin{array}{c}\text { strong } \\
\text { TRD }\end{array}$ & $\begin{array}{c}\text { moderate } \\
\text { TRD }\end{array}$ & $\begin{array}{l}\text { weak } \\
\text { TRD }\end{array}$ & $\begin{array}{c}\text { strong } \\
\text { GS }\end{array}$ & $\begin{array}{c}\text { moderate } \\
\text { GS }\end{array}$ & $\begin{array}{c}\text { weak } \\
\text { GS }\end{array}$ & $\begin{array}{l}\text { strong } \\
\text { CW }\end{array}$ & $\begin{array}{c}\text { moderate } \\
\text { CW }\end{array}$ & $\begin{array}{c}\text { weak } \\
\text { CW }\end{array}$ & $\begin{array}{c}\text { Trees } \\
\text { aged } \\
>10 \\
\end{array}$ & $\begin{array}{c}\text { Affected } \\
\text { trees }\end{array}$ & $\begin{array}{l}\text { AAI } \\
\text { (\%) }\end{array}$ & $\begin{array}{l}W_{\text {it }} \\
(\%)\end{array}$ \\
\hline 2018 & 6 & 5 & 0 & 0 & 0 & 0 & 0 & 0 & 0 & 0 & 53 & 6 & 11 & 3.3 \\
\hline 2016 & 4 & 5 & 2 & 7 & 0 & 0 & 0 & 0 & 0 & 0 & 56 & 7 & 13 & 4.1 \\
\hline 2014 & 6 & 6 & 1 & 12 & 0 & 1 & 3 & 0 & 0 & 2 & 57 & 9 & 16 & 6.9 \\
\hline 2012 & 7 & 8 & 4 & 3 & 0 & 0 & 1 & 1 & 0 & 4 & 56 & 12 & 21 & 12.4 \\
\hline 2010 & 3 & 1 & 4 & 8 & 0 & 2 & 1 & 0 & 1 & 0 & 53 & 8 & 15 & 5.2 \\
\hline 2008 & 5 & 5 & 0 & 3 & 3 & 1 & 1 & 0 & 0 & 1 & 49 & 8 & 16 & 6.3 \\
\hline 2007 & 5 & 7 & 6 & 3 & 3 & 3 & 5 & 7 & 0 & 3 & 46 & 17 & 37 & 28.1 \\
\hline 2005 & 5 & 8 & 3 & 8 & 4 & 0 & 1 & 1 & 1 & 8 & 39 & 13 & 33 & 20.3 \\
\hline 1999 & 0 & 1 & 4 & 5 & 1 & 0 & 3 & 0 & 0 & 3 & 29 & 5 & 17 & 3.6 \\
\hline 1997 & 3 & 1 & 0 & 1 & 0 & 0 & 4 & 0 & 0 & 0 & 26 & 3 & 12 & 1.7 \\
\hline 1994 & 0 & 1 & 2 & 2 & 0 & 0 & 0 & 0 & 0 & 0 & 25 & 3 & 12 & 1.5 \\
\hline
\end{tabular}

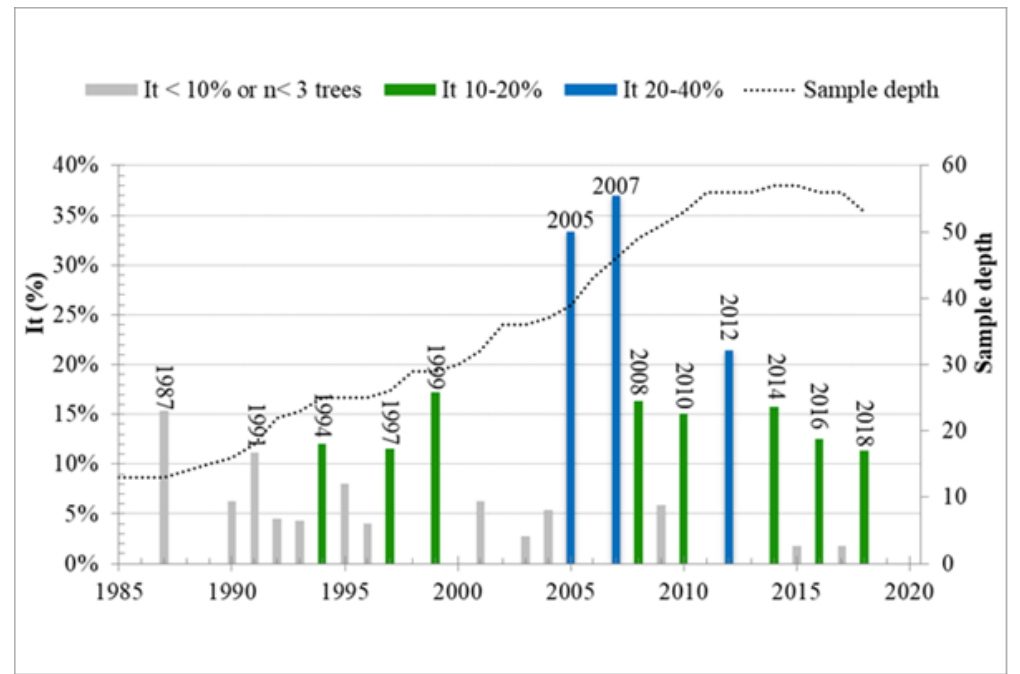

Figure 5 Reconstructed SAs chronology

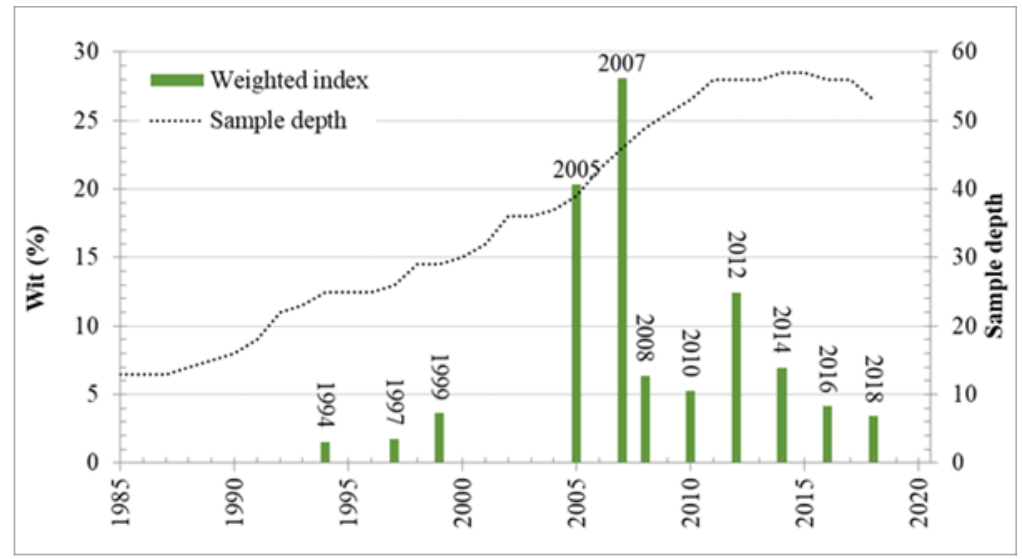

Figure 6 Intensity of growth disturbances expressed as Weighted index $\left(\mathrm{W}_{\mathrm{it}}\right)$ calculated for the reconstructed SAs years 
For each event year in the reconstructed chronology, a Weighted Index $\left(\mathrm{W}_{\mathrm{it}}\right)$ was calculated based on the intensity of the GDs, in order to assess the impact of the SAs on the sampled trees (Fig. 6). SAs which occurred during the winter seasons 20042005, 2006-2007, and 2011-2012 not only have been confirmed by a highest number of affected trees, but also by the highest number of the GDs of strong intensities. The other reconstructed event years show lower values of the $W_{\text {it. }}$. Figure 7 presents some examples of the spatial extension of SAs where in the winter seasons 2004-2005, 2006-2007 and 2011-2012 the entire path was affected.

\section{Discussion}

One of the limits of the dendrogeomorphic approach applied here to reconstruct SAs history is that it enabled to reconstruct the occurrence of a single SA per winter season, even if more than one SA occurred during the same winter period. Moreover, high-magnitude SAs are usually recorded by a high number of trees distributed spatially across the entire path, while low-magnitude SAs may not reach with sufficient velocity and impact all the trees inside the path, and consequently are not recorded. Spatial location of trees within the path has potentially a major influence on the possibilities to reconstruct SAs in different path sectors.

Trees, depending on their location on the left, median or right sides of the upper track area, may potentially be impacted by both low-magnitude and high-magnitude SAs, while trees located in the runout area are disturbed by those major SAs affecting the entire path. In this respect, considering the location of sampled trees within the Cârja path mainly on the left and right sides of the track area, we are aware that not all SAs have been reconstructed based on tree-ring analyses. Therefore, the results of the present study should be considered only as a minimum chronology of SAs activity along the Cârja path. An improved SAs chronology could be obtained by combining the tree-ring reconstruction with historical archives such as reported elsewhere (Corona et al., 2010b; Tumajer and Treml, 2015). In areas devoid of forest vegetation, other indirect information may be obtained regarding the patterns of SAs activity (SAs type, frequencies), ei- ther on short-term, as well as on long-term period. During successive campaigns, field observations may concern the geomorphic impact of SAs, and particularly the characteristics of transported debris by SAs, e.g., boulder size and orientation, plunging marks, colluvial cone deposit stratigraphy, etc. (Rapp, 1959, Nyberg, 1988, Decaulne and Saemundsson, 2006). Unfortunately, the lack of historical records in the Parâng Mountains and therefore tree-ring reconstruction cannot be completed by this source of information. A single event documented by newspapers and witnessed by members of Mountain Rescue Public Service (MRPS) occurred in December $1^{\text {st }} 2017$, and related with the loss of one human life. Therefore, tree-ring reconstruction may be considered as the method closest to absolute dating of SAs activity that can be used presently in the study area. The scientific community shows different opinions regarding the suitable sample size and the minimum threshold value of AAI to consider an avalanche event (Decaulne et al., 2012). By comparing historical archives with dendrogeomorphic reconstructions, Corona et al. (2012) suggested a sample size of approximately 100 trees in order to obtain a more complete SAs chronology. Some authors reported sample sizes less than 20 trees unreliable for avalanche reconstruction (Butler et al., 1987). The minimum threshold of AAI should be variable depending on the sample size, varying from 10\% (Boucher et al., 2003; Dubé et al., 2004; Germain et al., 2005; Reardon et al., 2008) to $40 \%$ for the identification of high-magnitude events (Butler and Malanson, 1985; Muntán et al., 2009). However, there is no general agreement on defining a specific sampling size which may be applied in all tree-ring reconstructions of SAs. Although a sampling size around 100 trees could be useful in some mountain areas with large paths (Corona et al., 2010b), in other mountain areas with small paths and/or less dense tree cover may not be applied. Choosing a suitable sampling size to reconstruct SAs in an area is still subjective by the expert judgement and depends on various sampling strategies applied, available trees for sampling, sample type which may be obtained (discs, wedges or cores), various resources involved during field-sampling (time, experts, equipment, etc.). 

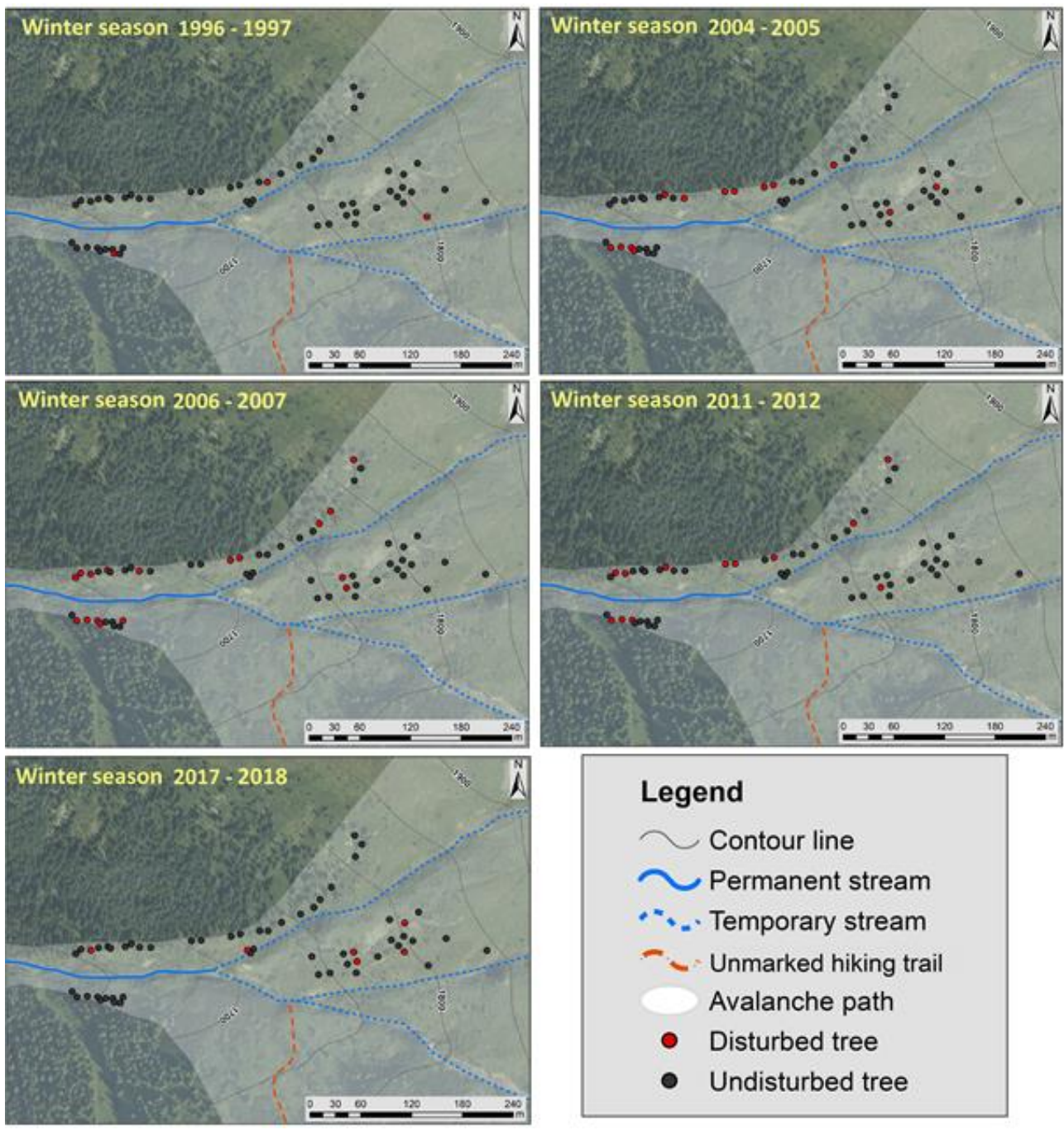

Figure 7 Spatial distribution of disturbed trees for winter seasons: 1996-1997, 2004-2005, 2006-2007, 2011-2012 and 2017-2018

In the present study, giving the morphometric features of the investigated path (relatively small size, confined path), the small density of tree cover inside the path, the possibility to collect samples of high quality (discs) due to availability of the uprooted trees left after the 2017 SA event, and the limited time resources dedicated to field investigations, a medium sample size was considered as suitable. A minimum threshold of $10 \%$ was used and considered suitable to reconstruct past SA events, but we are aware that a larger sample size would likely enable to extent the chronology and improve the historical reconstruction of past SA events. However, it is also interesting to mention that some of the reconstructed SA winters have also been documented in the Romanian Carpathians. Indeed, the years
2005 and 1997 were also recorded in the previous tree. The scientific community shows different opinions regarding the suitable sample size and the minimum threshold value of AAI to consider an avalanche event (Decaulne et al., 2012). By comparing historical archives with dendrogeomorphic reconstructions, Corona et al. (2012) suggested a sample size of approximately 100 trees in order to obtain a more complete SA chronology. Some authors reported sample sizes less than 20 trees unreliable for avalanche reconstruction (Butler et al., 1987). The minimum threshold of AAI should be variable depending on the sample size, varying from $10 \%$ (Boucher et al., 2003; Dubé et al., 2004; Germain et al., 2005; Reardon et al., 2008) to $40 \%$ for the identification of high-magnitude events (Butler and Malan- 
son, 1985; Muntán et al., 2009). However, there is no general agreement on defining a specific sampling size which may be applied in all tree-ring reconstructions of SAs. Although a sampling size around 100 trees could be useful in some mountain areas with large paths (Corona et al., 2010b), in other mountain areas with small paths and/or less dense tree cover may not be applied. Choosing a suitable sampling size to reconstruct SAs in an area is still subjective by the expert judgement and depends on various sampling strategies applied, available trees for sampling, sample type which may be obtained (discs, wedges or cores), various resources involved during field-sampling (time, experts, equipment, etc.). ring-based chronologies either from Parâng Mountains (Pop et al., 2016; Meseşan et al., 2019) and other mountain ranges in the Southern and Eastern Carpathians (Voiculescu and Onaca, 2013; Chiroiu et al., 2015; Pop et al., 2017; Pop et al., 2020). In that regard, further investigations on other avalanche paths in Parâng Mountains are needed, in order to analyse the weather conditions and patterns that are likely favourable to the triggering of SAs at a regional scale in the Carpathian Range.

\section{Conclusions}

The type, amount and intensities of growth disturbances found within the tree rings enabled the reconstruction of SA history for the period 1994-2018. Within the investigated avalanche path, the treering based chronology shows the occurrence of a minimum of 11 significant SA events, with an average return period of 2.1 years. Tree-ring records provided the most consistent avalanche chronology and may further contribute to an accurate avalanche hazard zonation in the study area. As most of the avalanche paths in the area are crossed by tourist hiking trails, reconstruction of SAs activity over the last decades should be extended to the whole Parâng Mts., in order to improve the risk assessment at a regional scale. The results of the present study and other similar studies can help the Mountain Rescue Team and local administration in increasing the awareness about SAs location, frequency, and magnitude. Finally, although the limited extension of the chronology back in time, this represents nonetheless useful and pertinent information to consider before the implementation and development of infrastructure in this mountain avalancheprone area.

\section{References}

Badea L, Niculescu G, Roată S, Buza M, Sandu M. 2001. Unitățile de relief ale României - Vol. I: Carpații Meridionali și Munții Banatului. Ed. Ars Docendi, Bucharest, vol. 1, ISBN 973-0-02290-9 (in Romanian).

Bräker OU. 2002. Measuring and data processing in treering research - a methodological introduction. Dendrochronologia 20(1-3): 203-216.

Boucher D, Filion L, Hétu B. 2003. Reconstitution dendrochronologique et fréquence des grosses avalanches de neige dans un couloir subalpin du mont Hog's Back, Gaspésie Centrale (Québec). Géographie Physique et Quaternaire 57: 159-168.

Bryant, C.L., Butler, D.R. \& Vitek, J.D., 1989. A statistical analysis of tree-ring dating in conjunction with snow avalanches: Comparison of on-path versus off-path responses. Environmental Geology and Water Sciences 14(1): 53-59.

Butler DR, Malanson GP. 1985. A history of high-magnitude snow-avalanches, southern Glacier National Park, Montana, USA. Mountain Research and Deve/opment 5: 175-182.

Butler DR, Walsh SJ, Oelfke JG. 1987. Tree-Ring Analysis and Natural Hazard Chronologies: Minimum Sample Sizes and Index Values. Professional Geographer 39: 41-47.

Casteller A, Stockli V, Villalba R, Mayer AC. 2007. An evaluation of dendroecological indicators of snow avalanches in the Swiss Alps. Arctic, Antarctic and Alpine Research 39: 218-228.

Chiroiu P, Stoffel M, Onaca A, Urdea P. 2015. Testing dendrogeomorphic approaches and thresholds to reconstruct snow avalanche activity in the Făgăraș Mountains (Romanian Carpathians). Quaternary Geochronology 27:1-10.

Cook E, Kairiukstis L. 1990. Methods of dendrochronology: applications in the environmental sciences. Kluwer Academic Publishers, Dordrecht, The Netherlands, 394 p.

Corona C, Rovéra G, Lopez-Saez J, Stoffel M, Perfettini P. 2010a. Spatio-temporal reconstruction of snow avalanche activity using tree rings: Jean Jeanne avalanche talus, Massif de l'Oisans, France. Catena 83: 107-118.

Corona C, Saez JL, Stoffel M, Bonnefoy M, Richard D, Astrade L, Berger F. 2010b. How much of the real avalanche activity can be captured with tree rings? An 
evaluation of classic dendrogeomorphic approaches and comparison with historical archives. Cold Regions Science and Technology 74 (75): 31-42

Corona C, Saez JL, Stoffel M, Bonnefoy M, Richard D, Astrade L, Berger F. 2012. How much of the real avalanche activity can be captured with tree rings? An evaluation of classic dendrogeomorphic approaches and comparison with historical archives. Cold Regions Science and Technology 74-75: 31-42.

Decaulne A, Sæmundsson P. 2006. Geomorphic evidence for present-day snow-avalanche and debris-flow impact in the Icelandic Westfjords. Geomorphology $\mathbf{8 0}$ : 80-93.

Decaulne A, Eggertsson Ó, Sæmundsson P. 2012. A first dendrogeomorphologic approach of snow avalanche magnitude-frequency in Northern Iceland. Geomorphology 167-168: 35-44.

Dubé S, Filion L, Hétu B. 2004. Tree-ring reconstruction of high-magnitude snow avalanches in the Northern Gaspé Peninsula, Québec, Canada. Arctic, Antarctic and Alpine Research 36: 555-564.

Gardner J. 1970. Geomorphic significance of avalanches in the Lake Louise area, Alberta, Canada. Arctic and A/pine Research 2: 135-144.

Gavrilă, IG, Horvath C, Meseşan F, Pop O. 2018. Snow avalanche

susceptibility mapping using GIS in Parâng Mountains, Proceedings of 34th Romanian National Symposium on Geomorphology and 19th Joint Geomorphological Meeting, Buzău.

Germain D, Filion L, Hétu B. 2005. Snow avalanche activity after fire and logging disturbances, Northern Gaspé Peninsula, Quebec, Canada. Canadian Journal of Earth Sciences 42: 2103-2116.

Holmes RL. 1983. Computer-assisted quality control in tree-ring dating and measurement. Tree-ring Bulletin 43: 69-78.

Kogelnig-Mayer B, Stoffel M, Schneuwly-Bollschweiler M, Hübl J, Rudolf-Miklau F. 2011. Possibilities and limitations of dendrogeomorphic time series reconstructions on sites influenced by debris flows and frequent snow avalanche activity. Arctic, Antarctic, and Alpine Research 43(4): 649-658.

Meseşan F, Man TC, Pop OT, Gavrilă IG. 2019. Reconstructing snow-avalanche extent using remote sensing and dendrogeomorphology in Parâng Mountains, Cold Regions Science and Technology 157: 97-109.

Muntán E, García C, Oller P, Martí G, García A, Gutiérrez E. 2009. Reconstructing snow avalanches in the southeastern Pyrenees. Natural Hazards and Earth System Sciences 9: 1599-1612.

Nyberg R. 1989. Observations of slushflows and their geomorphological effects in the Swedish Mountain area.
Geografiska Annaler Series A - Physical Geography 71: 185-198.

Pop OT, Gavrilă IG, Roșian G, Meseşan F, Decaulne A, Holobâcă

IH, Anghel T. 2016. A century-long snow avalanche chronology reconstructed from tree rings in Parâng Mountains (Southern Carpathians, Romania). Quaternary Internationa/ 415: 430-440.

Pop OT, Munteanu A, Meseşan F, Gavrilă IG, Timofte C, Holobâcă,

IH. 2017. Tree-ring-based reconstruction of highmagnitude snow avalanches in Piatra Craiului Mountains (Southern Carpathians, Romania). Geografiska Annaler Series A - Physical Geography 100 (2): 99-115.

Pop OT, Holobâcă IH, Răchitǎ IG, Decaulne A, Hotea M, Horváth C. 2020. Reconstitution dendrochronologique des avalanches de neige et conditions synoptiques associées à l'épisode avalancheux majeur de I'hiver 2005 dans les Monts Maramureş (Carpates Orientales Roumaines). In: Bonnardot V, Quenol H, (eds.) Actes du XXXIIIe Colloque de L'Association Internationale de Climatologie, Rennes, France, 553558.

Rapp A. 1959. Avalanche boulder tongues in Lapland. Geografiska Annaler 41: 34-48.

Rayback SA. 1998. A dendrogeomorphological analysis of snow avalanches in the Colorado Front Range, USA. Physical Geography 19: 502-515.

Reardon BA, Pederson GT, Caruso CJ, Fagre DB. 2008. Spatial reconstructions and comparisons of historic snow avalanche frequency and extent using tree rings in Glacier National Park, Montana, USA. Arctic, Antarctic and A/pine Research 40:148-160.

RINNTECH. 2020. Technology for tree and wood analysis. http://www.rinntech.de/index-28703.html. Accessed Nov. 11, 2020

Schaerer PA. 1972. Terrain and vegetation of snow avalanches sites at Rogers Pass, British Columbia B.C. Geographical Series 14: 215-222.

Schweingruber FH. 1996. Tree Rings and Environment. Dendroecology. Paul Haupt, Bern, Switzerland, 609 p.

Shroder JF. 1978. Dendrogeomorphological analysis of mass movement, Table Cliff Plateau, Utah. Quaternary Research 9: 168-185.

Silhán K, Tichavský R. 2017. Snow-avalanche and debrisflow activity in the High Tatras Mountains: new data from using dendrogeomorphic survey. Cold Regions Science and Technology 134: 45-53.

Stoffel M and Bollschweiler M. 2008. Tree-ring analysis in natural hazards research - an overview. Natural Hazards and Earth System Sciences 8: 187-202. 
Stoffel M, Bollschweiler M, Hassler GR. 2006. Differentiating past events on a cone influenced by debris-flow and snow avalanche activity - a dendrogeomorphological approach. Earth Surface Processes and Landforms 31:1424-1437.

Stoffel M, Butler DR, Corona C. 2013. Mass movements and tree rings: A guide to dendrogeomorphic field sampling. Geomorphology 200: 106-120.

Stoffel M, Corona C. 2014. Dendroecological Dating of Geomorphic Disturbance in Trees. Tree-Ring $R e$ search 70(1): 3-20.

Tichavský R, Silhán K, Stoffel M. 2017. Age-dependent sensitivity of trees disturbed by debris flows - Implications for dendrogeomorphic reconstructions. Quaternary Geochronology 42: 63-75.

Tumajer I, Treml V. 2015. Reconstruction ability of dendrochronology in dating avalanche events in the Giant
Mountains, Czech Republic. Dendrochronologia 34: $1-9$.

Urdea P, Onaca A, Ardelean F, Ardelean M. 2011. New evidence on the Quaternary glaciations in the Romanian Carpathians. In: Ehlers J, Gibbard PL, Hughes PD (eds.), Developments in Quaternary Science: Quaternary Glaciations - Extend and Chronology. vol. 15. Elsevier, Amsterdam, The Netherlands, 305-322.

Voiculescu M, Onaca A. 2013. Snow avalanche assessment in the Sinaia ski area (Bucegi Mountains, Southern Carpathians) using the dendrogeomorphology method. Area 45:109-122.

Ward RGW. 1985. Geomorphological evidence of avalanche activity in Scotland. Geografiska Annaler Series A - Physical Geography, 67(3/4): 247-256. 